International Journal of Social Science And Human Research

ISSN(print): 2644-0679, ISSN(online): 2644-0695

Volume 04 Issue 04 April 2021

DOI: 10.47191/ijsshr/v4-i4-34, Impact factor-5.586

Page No : 803-806

\title{
Phraseological Units of the Concept of "Happiness" in Modern Chinese (On Material “中华五福古祥图典”)
}

\author{
Noiba Abbaskhonovna Valieva \\ $\mathrm{PhD}$ student Tashkent State University of Oriental Studies, Republic of Uzbekistan
}

ABSTRACT: The article provides a semantic analysis of phraseological units with the concept of "happiness" on the basis of lexicographic data “中华五福古祥图典”. The analysis of the concepts of “happiness”, represented by such components as 福, 禄, 寿, 喜 in the phraseological units of the concept sphere "happiness" is carried out.

KEYWORDS: Idiom, ready-made expression, emotiveness, cultural connotation, concept.

\section{INTRODUCTION}

In an era of rapid development, the need for interethnic dialogue and the mutual exchange different information is increasing. In recent decades, interethnic relations have been expanding, deepening, expanding, and are of daily nature. This, in turn, resulted in change. At the present stage, the growing need for an equivalent translation of words, traditional traditions and cultural customs is becoming more and more noticeable.

The term phraseology was introduced by the Swiss scientist S. Bally (1865-1947) in the meaning of "a section of stylistics that studies related combinations" [3, 8]. Subsequently, the study of phraseology was widely developed in Russian linguistics in the 1940s-1980s, based on the material mainly of the Russian language. A phraseological unit, a phraseological turnover are called semantically indivisible, stable combinations of words, which are characterized by the constancy of a special integral meaning, component composition and fixation in the speaker's memory. The term "phraseological meaning" was proposed in 1964 by A.V. Kunin and V.L. Arkhangelsk, independently of each other [3, 8]. The existence of phraseological meaning as a linguistic category is the subject of discussion among the researchers of phraseology. The nomination of the phenomena of reality by phraseological unit is associated with the internal form of phraseological units, which reflects in the mind the integral image of the situation. The internal form is a fundamental component of the semantics of a phraseological unit, because it (or rather its image) is a source of semantic motivation, cultural connotation, emotiveness, evaluativeness and stylistic characteristics of a phraseological unit [3, 9].

It should be noted that in the semantic and grammatical modeling of phraseology, some of its lexical units play a significant role, which cannot be denied. The relation of such lexical units to phraseology becomes grammatical, and their lexical meaning weakens. It should be noted that in the semantic structure of phraseology, it is not the denotative meanings of words that are important, but their connotative meanings specific to a particular lexical group.

成语 chéng yŭ (phraseological units) is a part of stereotyped phrases in the language dictionary [1,10]. Chinese phraseological units have a fixed structure and a fixed utterance, which express a certain meaning and are used in a sentence as a whole. Most of the phraseological units are inherited from ancient times, and they often differ from modern Chinese words [1, 11]. Among them are sentences from ancient books, phrases condensed from ancient articles, and idioms frequently used by humans. Phraseological units are a kind of ready-made words that are similar to idioms and proverbs, but differ slightly. The most significant point is that idioms and proverbs are spoken by nature, and most idioms are written and textual in nature. Second, from the point of view of linguistic form, phraseological units are almost all four-character structures established by conventions, and literals cannot be changed at will $[1,12]$.

Phraseology of the Chinese language has become an object of linguistic research relatively recently, in the 50s of the last century, therefore its boundaries have not yet been determined and the division of phraseological units into categories is not entirely clear. Traditionally, phraseological units are distinguished in Chinese philology: 成语chéngyŭ “Idiom, ready-made expression”,俗语

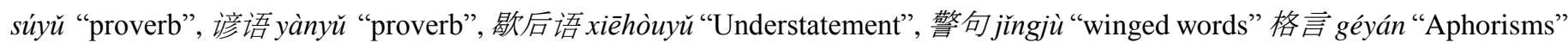
and 奇说 qishuo "paradox". Of the greatest interest of them are Chengyu, firstly, because they are much more numerous than other phraseological units, and secondly, because they are very often used in speech and the translator has to deal with them, Thirdly, 


\section{Phraseological Units of the Concept of “Happiness” in Modern Chinese (On Material “中华五福古祥图典”)}

Chengyu themselves are good material for studying both the current state of the lexical and grammatical means of the Chinese language, and their historical development $[4,195]$.

\section{MAIN PART}

Chengyu, along with other groups of Chinese phraseology, perform the function of the most expressive means of the modern Chinese language. They unusually accurately, vividly and in a short, perfected form reflect ordinary concepts, record the most significant typical cases, situations, state certain vital observations of nature and man, generalizations and conclusions from the experience of the past $[6,98]$.

In this article, the following examples of phraseological units (hereinafter PU) of the concept sphere "Happiness" served as material for semantic analysis.

双福拱寿 shuāngfú gǒngshòu - double blessing。

《神农经》:“玉桃服之长生不死。若不得早服之, 临死服之, 其尸毕天地不朽。”桃亦称寿桃, 在吉祥图案中喻长寿。蝙蝠取 其“福”音, 在吉祥图案中喻福。福为吉祥之总, 寿为最难得之福, “双福拱寿”寓意幸福、长寿成双[2,c.84]。

"Shénnóng jīng”: "Yù táo fú zhī chángshēng bùš̌. Ruò bùdé zăo fú zhī, lín sĭ fú zhī, qí shī bì tiāndì bùxiǔ.” Táo yì chēngshòutáo, zài jíxiáng tú'àn zhōng yù chángshòu. Biānfú qù qí "fü” yīn, zài jíxiáng tú'àn zhōng yù fú. Fú wéi jíxiángzhī zǒng, shòu wèi zuì nándé zhī fú, "shuāng fú gǒngshòu” yùyì xìngfú, chángshòu chéngshuāng.

The Chinese book 《神农经》 speaks of a kind of magic peach: it turns living people into immortals, and the bodies of the dying remain for a while if they eat the fruit. The peach, also known as the longevity peach, symbolizes longevity in "happiness" paintings. In the hieroglyph 蝙蝠 bat the second sound is pronounced “fu”, just like the hieroglyph “happiness”, which here indicates longevity. As a result, longevity is the rarest blessing, and "double blessing" means happiness and longevity. Most likely, this linguocultural phenomenon can explain why the Chinese eat a bat.

三星高照 sānxīng gāozhào - high above three stars shine, be born under a lucky star.

《礼记. 中庸》: “日月所照。”旧时有句: “天上日月星, 人间福祿寿。”福, 为“五福”之总; 禄, 即俸禄, 钱财, 是人们生活的基础, 旧时称“没什么别没钱”。寿, 为“五福”之首。我国自古就有星象崇拜, 故把福、禄、寿称“三星”。

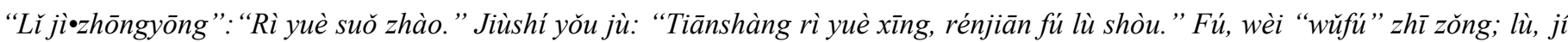
fènglù, qiáncái, shì rénmenshēnghuó de jīchǔ, jiùshí chēng "méishénmebié méi qián”. Shòu, wèi "wǔfú” zhī shǒu. Wǒguó zìgǔ jiù yǒu xīngxiàngchóngbài, gù bă fú, lù, shòu chēng "sānxīng”.

Ritual Book 《礼记. 中庸》: “The sun and the moon both shine.” There is an old saying: “The sun, moon and stars are in the sky, but on earth there is happiness, service well-being and longevity among people." 福Fu is the main of the "five blessings"; 禄 Lu is wages, money, the basis of people's lives, and they used to say "there is money, there is everything". Longevity is the first of the Five Blessings. Astrological worship has existed in China since ancient times, so 福 Fu, 禄 Lu and 寿 Shou are called “three stars."

龙凤呈祥 lóngfèng chéngxiáng - happy marriage (wish for a happy marriage)

龙、凤是中国古代传说中最大的神物。龙为万灵之长, 是权威、尊贵的象征, 视为最高男性的代表。凤是百鸟之长, 是美丽、 仁爱的象征, 视为最高女性的代表。旧俗常把男女婚烟之喜比作“龙凤呈祥”, 是对幸福的祝颂。

Lóng, fèng shì zhōngguó gǔdài chuánshuō zhōng zuìdà de shén wù. Lóng wèi wàn líng zhī cháng, shì quánwēi, zūnguì de xiàngzhēng, shì wéi zuìgāo nánxìng de dàibiăo. Fèng shì băi niăo zhī cháng, shì měilì, rén'ài de xiàngzhēng, shì wéi zuìgāo nüxìng de dàibiǎo. Jiùsú cháng bă nánnü hūn yān zhī xǐ b̌̌ zuò "lóngfèng chéng xiáng”, shì duì xìngfú de zhù sòng

龙 Dragon and 凤 Phoenix are the largest mythological animals in ancient Chinese legends. The dragon is the largest creature among ten thousand souls, a symbol of power and dignity, and is considered the personification of a man. Phoenix is the largest among hundreds of birds, a symbol of beauty and goodwill, is considered the personification of a woman. According to old customs, the joy of marriage between a man and a woman is often compared to "a thriving dragon and phoenix," which is a blessing of happiness.

连年有余 liánnián yǒuyú - wish abundance from year to year

在中国, 鱼为吉祥之物。古代有“鱼符”, 又称“鱼契”, 为权力信物。接载唐朝时曾赐发给百官以“鱼符”, 木雕或铜铸成鱼 形,上面刻字, 合半为一, 以为凭物。“鱼”与“余”谐音,故以“鱼”示“余”。余者富之余连年有富余。

Zài zhōngguó, yú wéi jíxiáng zhī wù. Gǔdài yǒu “yú fú”, yòu chēng “yú qì”, wèi quánlì xìnwù. Jiē zài tángcháoshí céngcîfā gèi

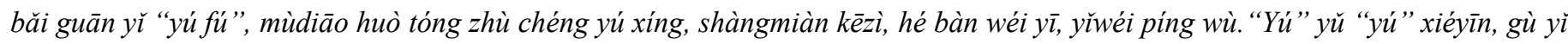
"yú” shì "yú”. Yú zhě fù zhī yú, liánnián yǒu fùyú.

In China, fish is a creature that symbolizes happiness. In ancient times, there was a "fish symbol", also known as "fish feat", which was a sign of power. During the Tang Dynasty, it was presented to hundreds of officials with a "fish symbol" carved from 


\section{Phraseological Units of the Concept of “Happiness” in Modern Chinese (On Material “中华五福古祥图典”)}

wood or copper in the shape of a fish and engraved on it. "Yú" fish and "yú" abundance are homophonic, so "yú" fish is used to express "yú" abundance. Wish abundance from year to year.

This phraseological unit shows that the Chinese have always believed that if there is abundance, there will be happiness, that is, happiness is closely related to prosperity, abundance.

女娲补天 nü wā bǔ tiān-majestic spirit, fearless fighting spirit.

女娟, 是我国古代神话中创造人 类的女神。相传天地开裂后, 是女娲 技黄土做人, 才有了人类。后水神共工与火神祝融相 头, 破坏了人类的安宁生活, 引起天塌地裂。于是女娲炼五色石补天, 斩鳌足撐天地, 拯救了人类。

Nü juān, shì wǒguó gŭdài shénhuà zhōng chuàngzào rénlèi de nǘshén. Xiāngchuán tiāndì kāiliè hòu, shì nü wā jì huángtǔ zuòrén, cái yǒule rénlèi. Hòu shǔ̌shén gòng gōng yǔ huǒ shén zhùróng xiāng dòu, pòhuàile rénlèi de ānníng shēnghuó, y̌nqǔ tiān tā dì liè. Yúshì nü wā liàn wǔsè shí bǔ tiān, zhăn áo zú chēng tiāndi, zhěngjiùle rénlèi.

Nuva is the goddess who created people in the ancient myths of my country (China). Legend has it that after the world shattered, it was Nuva who used (she was knead the earth) the earth to create humans, and then humans were born. The battle between the God of water Gong Gong and the God of the volcano Zhu Rong destroyed the peaceful life of mankind and led to the collapse of the world. Then, Nuva perfected a five-color stone to fill the sky, cut off the legs to support the sky, and saved humanity.

The fact that the woman-goddess saved humanity and the world shows that in China women have always been considered the foundation and savior of the nation. This can be viewed as a gender factor, since the role of women in Chinese society has been special and important since ancient times.

日月合璧 rì yuè hé bì - harmony, favorable conditions

《汉书, 律历志上》: “日月如合壁五星如连珠。”日月同升, 出现于阴历的朔日, 在我国很少见。古人附会为国实的祥瑞。

《诗经, 小雅天保》: “如月之恒如日之升。”日月是永恒的, 江河炳地, 日月恒天。

Hàn shū, lù lì zhì shàng”" "Rì yuè rú hé bì, wǔxīng rú liánzhū." Rì yuè tóng shēng, chūxiàn yú yīnlì de shuòrì, zài wǒguó hèn shăo jiàn. Gǔrén fùhuì wèi guójiā de xiángruì. "Shījīng, xiăo yă tiānbăo": "Rúyuè zhī héng, rú rì zhī shēng." Rì yuè shì yǒnghéng de, jiānghé bìng de, rì yuè héng tiān.

"Han Shu, Lui Li Zhi Shan": "The sun and the moon are like a wall, and the five stars are like a pearl." The sun and the moon rise together and will be in harmony, new days of the lunar calendar appear, that is, this phenomenon is rare in our country (in China). Ancient people tied it to the favorable conditions of the country. "Book of Songs, Xiaoyi Tianbao": "As the moon is constant, so the sun rises." The sun and the moon are eternal, as rivers and lakes are eternal.

This phraseological unit shows how the Chinese people initially related to the state, the emperor, since the concept of happiness is associated with the state and its harmony with the people. In the process of analyzing this phraseological unit, the second part, i.e. 日月合璧,五星连 rì yuè hébì, wǔxīng liánzhū - this is the full version. Here you can see the connection with the concept of 五 行 wǔ xíng wu Xing is five movements. And since energy is a measure of motion, it is also five energies. Energy and mothers are distinct entities. Wu Xing is a system that came to us from ancient times, when there was no written language and knowledge from generation to generation passed on in capacious symbols such as a cross and a star [6,35]. Also in the formation of Wu Xing, the school of natural philosophy played an important role. The first natural philosophical ideas about the two principles of yin-yang, as well as about the five primary elements of using, can be traced already in the images on the Neolithic ceramics of the 4th-2nd millennium BC. Probably, over time, two independent traditions "heavenly" (astronomical and astrological) have developed and "earthly" (mantico-economic), which considered, respectively, the concepts of yin-yang and five primary elements. Approximately in the 5th century BC among the court astronomers and astrologers, the school of natural philosophers was born, which united them [10]

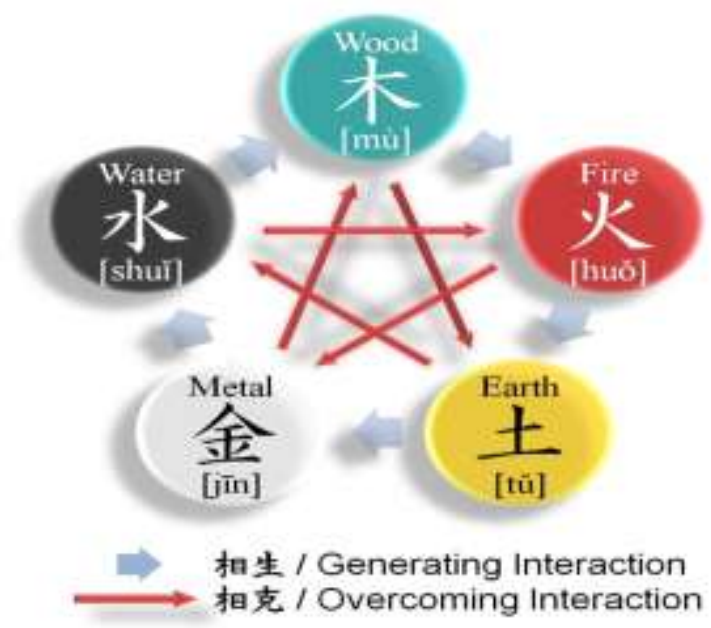




\section{Phraseological Units of the Concept of “Happiness” in Modern Chinese (On Material “中华五福古祥图典”)}

In the arrangement of the 5 movements of Wu Xing on the pentagram, at the first glance, 2 sequences are visible: the sequence of generation (in a circle) the sequence of suppression (along the star) the elements of Wu Xing are in the cycle of generation. The tree gives rise to Fire. Fire gives birth to the Earth. The Earth gives birth to Metal. Metal gives birth to Water. Water gives birth to Wood. In the suppression sequence, the Tree is holding the Earth by its roots. The earth absorbs Water. Water extinguishes Fire. Fire melts Metal. Metal cuts Wood [5, 9].

Thanks to the understanding of the concept of the five elements, we can consider this phrase more deeply, because Wu Xing's concept is fundamental not only in philosophy, but also in Chinese medicine, martial arts, gymnastics, cooking and, in part, linguistics. Literally translated, the moon and sun are in a circle, and five stars or five elements are interconnected. All the elements are in one place in the sequence, they are all in harmony and endless. The state will prosper if everything is balanced, and this way of managing to keep everything in balance is eternal.

The analysis showed that for the transmission of the concept of "happiness" it is not necessary to have a hieroglyph 福fú. This concept of happiness can be conveyed by other units mentioned above. Therefore, the concept of "happiness" in Chinese includes such concepts as: joy, longevity, beneficence, career and wealth.

Based on the material “中华五福古祥图典”, 595 units of the “happiness” semantic field were analyzed from the point of view of the Chinese mentality. Of these, the most frequently expressing the concept of happiness were $250 \mathrm{PU}$ with five components 喜xĭ, 寿 shòu, 福fú, 禄 lù, 财 cái. All hieroglyphs are translated differently, but they all belong to the same concept sphere - the concept sphere of happiness.

\section{CONCLUSION}

In the Chinese language the concept of "happiness" is not only represented by the concept of 福 fú happiness. This concept is closely related to concepts such as 寿 shòu longevity, 禄 lù welfare, 财 cái wealth and 喜 xǐ conjugal happiness. All phraseological units semantically have a connection with the ancient philosophical traditions of Chinese society, and therefore they cannot be viewed in a cut from each other, but it is advisable to analyze within a single concept, which will allow the reader to understand such commonplace things for the Chinese as eating a bat. Based on the above, we can conclude that Chinese phraseological units show in general the entire evolution of the Chinese people to the present day.

\section{REFERENCES}

1) 中国大百科全书, 语言文字, 中国大百科会素出版社, - 北京., 1998.

2) 黄全信，中华五福吉祥图典，华语教学出版社, - 北京 2003.,- - p.245.

3) Guo Ninnin. Lexicographic development of Russian phraseology (for the explanatory-translated Russian-Chinese phraseological dictionary): Abstract of the thesis ... candidate of philological sciences. Moscow: 2013. - p.20

4) Gotlib O.M., Mu Huayin, Chinese-Russian phraseological Dictionary. -Irkutsk, 2019. - p. 596

5) Jin Geh, Li Chun. Destiny Code, BaZi. Moscow: Eksmo, 2017, -p. 606.

6) ana K.A. Influence of Usin philosophy on the etymology and semantics of the Chinese language (on the example of certain groups of words) // Russia-China: history and culture. Kazan: 2020. -p. 35

7) Klenin I.D., Shchichko V.F. Lexicology of the Chinese language. Moscow: 2013. -p. 195

8) Oshanin I.M. (ed.) The Great Chinese-Russian Dictionary.T. 1-4. Moscow: Hayka, 1983-1984. - p.1062

9) Toropov A.A. Chenyu and their properties // Controversial issues of the Chinese language. Moscow: 1965. -p. 111

10) Chinese-Russian Dictionary / Comp. Fu Chong. Shanghai: 2004. -p. 1249

11) https://profenshuy.com/stihiya/pyat-stihij-kitajskoj-filosofii html

12) http://chengyu.t086.com/c b4f4

13) http://xh.5156edu.com/html5/79339.html

14) https://elar.urfu.ru/bitstream/10995/19275/1/iurp-2010-81-04.pdf 